\title{
Optimization of Nitrogen Rate and Planting Density for Improving Yield, Nitrogen Use Efficiency, and Lodging Resistance in Oilseed Rape
}

\author{
Shahbaz Khan, Sumera Anwar, Jie Kuai, Sana Ullah, Shah Fahad and Guangsheng Zhou *
}

College of Plant Science and Technology, Huazhong Agricultural University, Wuhan, China

Yield and lodging related traits are essential for improving rapeseed production. The objective of the present study was to investigate the influence of plant density (D) and nitrogen $(\mathrm{N})$ rates on morphological and physiological traits related to yield and lodging in rapeseed. We evaluated Huayouza 9 for two consecutive growing seasons (2014-2016) under three plant densities (LD, 10 plants $\mathrm{m}^{-2}$; MD, 30 plants $\mathrm{m}^{-2}$; HD, 60 plants $\mathrm{m}^{-2}$ ) and four $\mathrm{N}$ rates $\left(0,60,120\right.$, and $\left.180 \mathrm{~kg} \mathrm{ha}^{-1}\right)$. Experiment was laid out in split plot design using density as a main factor and $\mathrm{N}$ as sub-plot factor with three replications each. Seed yield was increased by increasing density and $N$ rate, reaching a peak at HD

OPEN ACCESS

Edited by:

Karl H. Muehling,

University of Kiel, Germany

Reviewed by:

Hans-Peter Kaul,

University of Natural Resources and Life Sciences, Vienna, Austria

Bernd Honermeier,

University of Giessen, Germany

*Correspondence:

Guangsheng Zhou zhougs@mail.hzau.edu.cn

Specialty section:

This article was submitted to

Plant Nutrition,

a section of the journal

Frontiers in Plant Science

Received: 03 December 2016 Accepted: 24 March 2017

Published: 09 May 2017

Citation:

Khan S, Anwar S, Kuai J, Ullah S,

Fahad S and Zhou G (2017)

Optimization of Nitrogen Rate and

Planting Density for Improving Yield,

Nitrogen Use Efficiency, and Lodging

Resistance in Oilseed Rape.

Front. Plant Sci. 8:532.

doi: 10.3389/fpls.2017.00532 with $180 \mathrm{~kg} \mathrm{~N} \mathrm{ha}^{-1}$. The effect of $\mathrm{N}$ rate was consistently positive in increasing the plant height, pod area index, 1,000 seed weight, shoot and root dry weights, and root neck diameter, reaching a peak at $180 \mathrm{~kg} \mathrm{~N} \mathrm{ha}^{-1}$. Plant height was decreased by increasing $\mathrm{D}$, whereas the maximum radiation interception ( $80 \%)$ and net photosynthetic rate were recorded at $\mathrm{MD}$ at highest $\mathrm{N}$. Lodging resistance and nitrogen use efficiency significantly increased with increasing $D$ from 10 to 30 plants $\mathrm{m}^{-2}$, and $\mathrm{N}$ rate up to $120 \mathrm{~kg} \mathrm{ha}^{-1}$, further increase of $D$ and $N$ decreased lodging resistance and NUE. Hence, our study implies that planting density 30 plants $\mathrm{m}^{-2}$ can improve yield, nitrogen use efficiency, and enhance lodging resistance by improving crop canopy.

Keywords: rapeseed, plant density, yield, lodging, nitrogen use efficiency

\section{INTRODUCTION}

Rapeseed (Brassica napus L.) is the third most important worldwide oil crop, after soybean and palm oil. In 2014, rapeseed was produced on $36.12 \mathrm{M}$ ha globally, mainly in China (7.59 M ha), Canada (8.07 M ha), and the European Union (6.71 M ha; Food and Agriculture Organization of the United Nations, 2017). It is one of the major oilseed crops in China, yielding 11.6 million tons per year. Yangtze River Basin is the largest rapeseed production region in China, with about $90 \%$ of national rapeseed production (Li et al., 2016). Many climatic and agronomic factors affect rapeseed yield, including lodging, plant density and fertilizers rates. Direct drill planting and mechanized harvesting has enabled farmers to gain higher yield of rapeseed from attaining higher plant densities (Hu et al., 2016). Although previous studies reported that after a saturation threshold, yield per unit area does not increase with plant density because of high intra specific competition for resources (Raey and Ghassemi-Golezani, 2009). Al-Barzinjy et al. (1999) showed that dry biomass per plant, seed weight per plant and number of pods per plant decrease with increasing plant density, whereas seed yield $\mathrm{m}^{-2}$ peaks at 50 plants $\mathrm{m}^{-2}$ and decreases at higher densities, following a parabolic curve relationship. Likewise, relatively low plant densities decrease the overall rapeseed yield by 
promoting vegetative but not reproductive growth (Bagheri et al., 2011). Therefore, desired plant density needs to be attained before the onset of the reproductive stage, a stage at which canopy reaches its maximum size, by changing seeding rates and row spacing (Purcell et al., 2002; Wang C. et al., 2015; Wang R. et al., 2015).

Nitrogen $(\mathrm{N})$ is a macronutrient that significantly affects yield and growth in rapeseed plants. However, plant requirements for $\mathrm{N}$ vary with cultivar, growth stage of plant, $\mathrm{N}$ utilization efficiency, soil type, climate, and type of $\mathrm{N}$ application (Sidlauskas and Bernotas, 2003; Berry et al., 2010). Previous studies aimed to optimize the rate of $\mathrm{N}$ to increase rapeseed yield (Kazemeini et al., 2010). Applying fall nitrogen to oilseed rape is common practice in China and Europe. In the last few years, farmers have changed the crop rotation; in consequence, the sowing date is often delayed. In addition, they increasingly pass on plowing during seedbed preparation to reduce energy costs. In order to compensate for delayed sowing, they additionally apply about $30-50 \mathrm{~kg} \mathrm{~N} / \mathrm{ha}$ in fall, often directly upon the stubble of the preceding crop, to ensure adequate crop growth before winter. Application of $\mathrm{N}$ increases the yield by improving growth, but its excessive use leads to higher production costs, increase risk of nitrate leaching and water contamination and reduce nitrogen use efficiency (Sieling and Kage, 2010; Zhang et al., 2013). Additionally, high $\mathrm{N}$ rates promote lodging by increasing plant height and raising the center of gravity and by decreasing lignin and cellulose content as well as stem diameter and cell wall thickness of basal internodes (Wang et al., 2012; Zhang et al., 2013). Despite of its capacity to absorb $\mathrm{N}$ from the soil in fall and spring, the $\mathrm{N}$ use efficiency of rapeseed is low which is around half that for cereals (Sylvester-Bradley and Kindred, 2009). Improving the $\mathrm{N}$ use efficiency of rapeseed is therefore very important to ensure the competitiveness of this crop at agronomic, environmental, and economic levels. Improving yield under low $\mathrm{N}$ levels is a key step toward improving $\mathrm{N}$ use efficiency, and estimation of seed yield under different $\mathrm{N}$ regimes can be used as an indicator of global $\mathrm{N}$ use efficiency (Bouchet et al., 2016).

It has been hypothesized that rapeseed yield might be improved by optimizing density and $\mathrm{N}$ rates by alteration of canopy architecture, intercepted light and photosynthesis. Therefore, objectives of present field experiments were: (1) to examine the effects of different plant densities and $\mathrm{N}$ rates on yield, lodging resistance, $\mathrm{N}$ use efficiency in rapeseed and (2) to explore the relationship between lodging resistance and morphological and yield traits.

\section{MATERIALS AND METHODS \\ Site Characteristics and Field Trial Management}

The experiment was laid out in a split-plot design with three replications. The previous crop for the plots sown at both growing seasons was rice. The total experimental area was 840 $\mathrm{m}^{2}$, and the size of each main plot was $2 \times 40 \mathrm{~m}$ (width $\times$ length) containing four sub-plots. Three plant densities (LD, 10 plants $\mathrm{m}^{-2} ; \mathrm{MD}, 30$ plants $\mathrm{m}^{-2}$; and $\mathrm{HD}, 60$ plants $\left.\mathrm{m}^{-2}\right)$ were assigned to the main plots and four $\mathrm{N}$ rates $\left(\mathrm{N}_{0}, 0 \mathrm{~kg} \mathrm{~N} \mathrm{ha}{ }^{-1} ; \mathrm{N}_{60}, 60 \mathrm{~kg}\right.$ $\mathrm{N} \mathrm{ha}^{-1} ; \mathrm{N}_{120}, 120 \mathrm{~kg} \mathrm{~N} \mathrm{ha}^{-1}$; and $\mathrm{N}_{180}, 180 \mathrm{~kg} \mathrm{~N} \mathrm{ha}^{-1}$ ) to the sub-plots. The treatments were replicated three times to give a total of 36 experimental units. Seeds of Huayouza 9, a rapeseed hybrid widely cultivated in central China, were manually sown in rows at a depth of 2-3 cm, on September 26, 2014 and October 4,2015 . Distance between the rows was maintained at $30-35 \mathrm{~cm}$. Distance within each row was adjusted by dense seeding and then thinned by hand to attain desired density rates when seedlings had reached at 4-5 leaves stage. Nitrogen was broadcasted as urea fertilizer $(46 \% \mathrm{~N})$, in three split doses: $50 \%$ before sowing, $30 \%$ during the over-wintering period, and $20 \%$ during the bud development period. No herbicides were applied to the field experiment and weeds were controlled by hand weeding. To control aphid, 50\% Imidacloprid, 40-60 g wettable powder was mixed in 40-50 L water and was sprayed in $667 \mathrm{~m}^{2}$ when aphid strain rate was $8 \%$. To control cabbage worm, $120 \mathrm{ml}, 48 \%$ chlorpyrifos EC 100-120 ml was sprayed in $667 \mathrm{~m}^{2}$, when larva 2-3 cm. Fungicide $40 \%$ dimethachlon $0.1-0.2 \mathrm{~kg} / 40-50 \mathrm{~L}$ water was sprayed at the beginning of flowering to control Sclerotinia sclerotiorum.

Soil samples were collected from the research field at a depth of 0-15 cm before sowing, air-dried, sieved, and analyzed in the laboratory using standard techniques. Total $\mathrm{N}$ was determined by the Kjeldahl method (Bremner, 1965). The available N content was determined using $1 \mathrm{M}$ potassium chloride $(\mathrm{KCl})$ extraction, followed by colorimetric analysis (Keeney, 1982). Available P was determined by the Olsen method according to Black (1965), organic content by the titrimetric method (Walkley and Black, 1934), and available K with a flame photometer (Knudsen et al., 1982). Physicochemical properties of the soil are presented in Table 1.

\section{Meteorological Conditions}

Meteorological data were collected for both growing seasons (2014/15 and 2015/16) from local weather station and they are presented in Table 2. The total hours of sunshine, accumulative temperature, and rainfall in 2014/2015 were slightly higher than those in the 2015/2016 growing season.

\section{Seed Yield and Yield-Related Traits}

On May 15, 2015 and May 18, 2016, at maturity 10 plants from each plot were randomly selected and roots were carefully dug out from $30 \mathrm{~cm}$ depth of soil by using a spade to determine plant height, root weight, root neck diameter, number of pods per plant, number of seeds per pod, and the weight of 1,000 seeds. Plant height was measured from the base to the highest bud. The roots were cut from the shoot, washed to remove soil, weighed, and root neck diameter was measured using Vernier calipers. The shoots and roots were oven-dried at $72^{\circ} \mathrm{C}$ until constant weight and their biomass was measured. The remaining plants in each plot were harvested by hand to measure seed yield. Pod area index was calculated from 10 randomly selected plants from each plot as follows: $\mathrm{Sa}=\pi \mathrm{d} \times\left(\mathrm{h}_{1}+1 / 3 \times \mathrm{h}_{2}\right)$, where $\mathrm{h}_{1}$ is 0.8 of the pod length, $h_{2}$ is 0.2 of the pod length, and $d$ is pod width. 
TABLE 1 | Physico-chemical properties of the soil before the study conducted in 2014/15 and 2015/16.

\begin{tabular}{|c|c|c|c|c|c|c|c|c|c|}
\hline $\begin{array}{l}\text { Soil samples } \\
\text { collected }\end{array}$ & Texture & $\mathrm{pH}$ & $\begin{array}{l}\text { Organic matter } \\
\qquad\left(\mathbf{g ~ k g}^{-1}\right)\end{array}$ & $\begin{array}{l}\text { Available } \mathrm{N} \\
\left(\mathrm{mg} \mathrm{kg}^{-1}\right)\end{array}$ & $\begin{array}{l}\text { Available P } \\
\left(\mathrm{mg} \mathrm{kg}^{-1}\right)\end{array}$ & $\begin{array}{l}\text { Available K } \\
\left(\mathrm{mg} \mathrm{kg}^{-1}\right)\end{array}$ & $\begin{array}{l}\text { Total } \\
\text { N (\%) }\end{array}$ & $\begin{array}{l}\text { Total } \\
\text { P (\%) }\end{array}$ & $\begin{array}{l}\text { Total } \\
\text { K (\%) }\end{array}$ \\
\hline 2014/15 & Silt clay loam & 6.45 & 8.01 & 64.5 & 9.81 & 148 & 0.07 & 0.03 & 1.11 \\
\hline 2015/16 & Silt clay loam & 6.12 & 8.40 & 72.4 & 10.30 & 145 & 0.09 & 0.04 & 1.40 \\
\hline
\end{tabular}

TABLE 2 | Meteorological conditions during the study conducted for two consecutive winter rapeseed-growing seasons.

\begin{tabular}{|c|c|c|c|c|c|c|}
\hline \multirow[t]{2}{*}{ Growing season } & \multirow[t]{2}{*}{ Meteorological condition } & \multicolumn{5}{|c|}{ Growth stages } \\
\hline & & Seedling & Wintering & Flowering & Pod filling & Total growth \\
\hline \multirow[t]{3}{*}{$2014 / 15$} & Total precipitation (mm) & 252.1 & 89.7 & 88.3 & 203.5 & 635.2 \\
\hline & Effective accumulated temperature $\left({ }^{\circ} \mathrm{C}\right)$ & $1,034.6$ & 24.6 & 240.9 & 565.9 & $1,833.6$ \\
\hline & Solar radiation $\left(\mathrm{MJ} \mathrm{m}^{-2}\right)$ & $1,656.3$ & 206.5 & 362.2 & 650.5 & $2,860.5$ \\
\hline \multirow[t]{3}{*}{ 2015/16 } & Total precipitation (mm) & 242.2 & 66.7 & 125.2 & 168.4 & 605.4 \\
\hline & Effective accumulated temperature $\left({ }^{\circ} \mathrm{C}\right)$ & 958.2 & 80.6 & 271.5 & 522.7 & $1,825.4$ \\
\hline & Solar radiation (MJ m-2) & $1,102.4$ & 190.1 & 341.4 & 525.5 & $2,065.3$ \\
\hline
\end{tabular}

\section{Lodging Resistance, Lodging Resistance Index (LRI), and Lodging-Related Morphological Traits}

A lodging tester (Hangzhou TOP Instrument Co., Hangzhou, China) was used to measure lodging resistance. The tester was set perpendicularly in the middle of the second basal internode, and the strength $(\mathrm{kg} \mathrm{cm})$ needed to break stem internode was measured. The LRI was computed as follows (Peng et al., 2014): LRI $=$ (stem height at the center of gravity $\times$ shoot fresh weight/breaking strength of the second basal internode) $\times 100$.

\section{Nitrogen Use Efficiency, Net Photosynthetic Rate, and Light Interception Ratio (LIR)}

Plant $\mathrm{N}$ concentration was determined by the micro-Kjeldahl method (Ozer, 2003). Apparent recovery nitrogen use efficiency (ARNUE) was evaluated (Li et al., 2014):

$$
\mathrm{ARNUE}=\left[\left(\mathrm{NU}_{\mathrm{fi}}-\mathrm{NU}_{\mathrm{f} 0}\right) / \mathrm{N}_{\mathrm{f}}\right] \times 100,
$$

Where, $\mathrm{NU}_{\mathrm{f}}: \mathrm{N}$ uptake of fertilized plants $\left(\mathrm{kg} \mathrm{ha}^{-1}\right), \mathrm{NU}_{\mathrm{f} 0}: \mathrm{N}$ uptake of unfertilized plants $\left(\mathrm{kg} \mathrm{ha}^{-1}\right), \mathrm{N}_{\mathrm{f}}$ : $\mathrm{N}$ fertilizer applied $\left(\mathrm{kg} \mathrm{ha}^{-1}\right)$.

Photosynthetic rate of the topmost, the middle, and the lowest leaf of intact plants was measured from 09:30 to 11:00 using Li6400 (Li-COR Inc., Lincoln, NE, USA) under a light intensity of $1,500 \mathrm{~mol} \mathrm{~m} \mathrm{~m}^{-2} \mathrm{~s}^{-2}$. Measurements for leaf photosynthesis were started at bud stage $(\mathrm{BBCH} 20)$ and performed with 14 days intervals until the onset of flowering (BBCH 60). Light interception refers to the amount of solar radiation intercepted by foliage and other green tissues. Light interception was measured using a SunScan Canopy Analysis System (Delta$\mathrm{T}$ Devices Ltd., UK), during the growing season until the onset of flowering (BBCH 20-60), between 11:00 and 15:00. To measure intercepted light, $1 \mathrm{~m}$ probe was set perpendicular to soil surface and two measurements were recorded above the canopy and two measurements below the canopy, with a third belowcanopy measurement in low-density plots. Light interception was calculated as (Liu et al., 2012):

$$
\begin{array}{r}
\operatorname{LIR}(\%)=[1-(\text { Average PAR below canopy } / \text { PAR above } \\
\text { canopy })] \times 100 .
\end{array}
$$

\section{Statistical Analysis}

Analysis of variance (ANOVA) in conjunction with Duncan's multiple range test was applied to identify significant differences between treatment levels and combinations of treatments at $p<$ 0.05. All analyses were carried out using SAS 8.1 (SAS Corp., Cary, NC, USA), and graphs were constructed using Microsoft Excel 2010 (Microsoft Corp., Redmond, WA, USA).

\section{RESULTS}

\section{Seed Yield and Yield-Related Traits}

The seed yield increased significantly with the increase in plant density and nitrogen in both growing seasons, reaching maximum levels at $\mathrm{HD}$ and $\mathrm{N}_{180}$ (Table 3). The weight of 1,000 seeds increased significantly with the application of nitrogen, reaching the maximum at $\mathrm{N}_{180}$, whereas plant density and $\mathrm{D}$ $\times \mathrm{N}$ did not affect significantly the 1,000-seed weight. Plant density had no significant effect on the effective number of pods per plant, whereas $\mathrm{N}$ had a significant positive effect, with the maximum number of pods per plant observed at $\mathrm{N}_{120}$ and minimum at $\mathrm{N}_{0}$. Under $\mathrm{LD}$, the number of branches increased with the increasing $\mathrm{N}$, reaching maximum at $\mathrm{N}_{180}$, however at higher densities, branches numbers increased up to $\mathrm{N}_{120}$, and declined at $\mathrm{N}_{180}$. The pod area index increased significantly with increasing plant density and $\mathrm{N}$ rate, reaching a peak at $\mathrm{HD}$ and $\mathrm{N}_{180}$ in both growing seasons (Table 3). 
TABLE 3 | Effect of plant densities and $\mathrm{N}$ rates on seed yield, 1,000-seed weight, number of pods per plant, number of branches, and pod area index in the growing season of 2014/15 (I) and 2015/16 (II).

\begin{tabular}{|c|c|c|c|c|c|c|c|c|c|c|c|}
\hline & & \multicolumn{2}{|c|}{ Seed yield $\left(\mathrm{kg} \mathrm{ha}^{-1}\right)$} & \multicolumn{2}{|c|}{1,000 grains weight $(g)$} & \multicolumn{2}{|c|}{ Effective pods (no. plant ${ }^{-1}$ ) } & \multicolumn{2}{|c|}{ Effective branches (no. plant ${ }^{-1}$ ) } & \multicolumn{2}{|c|}{ Pod area index } \\
\hline & & $\mathbf{I}$ & II & $\mathbf{I}$ & II & I & II & I & II & I & II \\
\hline \multicolumn{12}{|c|}{ TREATMENTS } \\
\hline \multirow[t]{3}{*}{ Density } & LD & 2,893 & 3,095 & 3.04 & 3.07 & 185.6 & 206.3 & 6.51 & 6.09 & 4.05 & 3.35 \\
\hline & MD & 3,216 & 3,276 & 2.98 & 3.08 & 195.5 & 208.3 & 6.11 & 5.50 & 4.46 & 4.23 \\
\hline & HD & 3,794 & 3,708 & 2.84 & 2.78 & 180.1 & 199.3 & 6.74 & 6.42 & 6.36 & 5.59 \\
\hline \multirow[t]{4}{*}{ Nitrogen } & 0 & 2,422 & 1,712 & $2.55 \mathrm{~B}$ & $2.72 \mathrm{C}$ & 69.3B & $86.9 \mathrm{~B}$ & 2.64 & 2.33 & 4.31 & 3.78 \\
\hline & 60 & 3,478 & 3,677 & $2.83 \mathrm{~B}$ & $2.94 \mathrm{BC}$ & $220.6 A$ & $240.1 \mathrm{~A}$ & 7.03 & 6.78 & 4.58 & 4.09 \\
\hline & 120 & 3,571 & 3,927 & $3.21 \mathrm{~A}$ & $3.07 \mathrm{AB}$ & $245.2 A$ & 243.9A & 8.05 & 7.45 & 5.29 & 4.53 \\
\hline & 180 & 3,732 & 4,122 & $3.21 \mathrm{~A}$ & $3.17 \mathrm{~A}$ & $213.1 \mathrm{~A}$ & $247.6 \mathrm{~A}$ & 8.09 & 7.45 & 5.64 & 5.15 \\
\hline \multicolumn{12}{|c|}{ INTERACTIONS } \\
\hline \multirow[t]{4}{*}{ LD } & 0 & $1,464 \mathrm{e}$ & $1,528 d$ & 2.60 & 2.73 & 50.2 & 62.5 & $2.30 f$ & $2.00 \mathrm{e}$ & $3.46 \mathrm{~h}$ & $3.09 e$ \\
\hline & 60 & $3,309 c$ & $3,374 c$ & 2.97 & 2.93 & 217.6 & 248.0 & $6.43 d$ & $6.00 d$ & 3.98fgh & $3.24 \mathrm{e}$ \\
\hline & 120 & 3,396bc & 3,701bc & 3.30 & 3.37 & 254.0 & 260.4 & 8.30ab & 7.67abc & $4.24 \mathrm{fg}$ & $3.49 e$ \\
\hline & 180 & $3,402 \mathrm{bc}$ & $3,777 \mathrm{bc}$ & 3.27 & 3.23 & 220.7 & 254.3 & $9.00 a$ & $8.67 a$ & 4.51ef & $3.56 \mathrm{e}$ \\
\hline \multirow[t]{4}{*}{ MD } & 0 & $2,563 d$ & $1,695 d$ & 2.73 & 2.93 & 91.3 & 117.0 & $2.10 f$ & $2.00 \mathrm{e}$ & 3.62gh & $3.43 e$ \\
\hline & 60 & 33,310c & $3,426 c$ & 2.83 & 3.10 & 233.0 & 236.0 & $6.90 \mathrm{~cd}$ & $6.33 d$ & 3.83gh & $3.63 e$ \\
\hline & 120 & 3,386bc & 3,926bc & 3.17 & 2.97 & 236.8 & 240.7 & $7.77 \mathrm{bc}$ & $7.00 \mathrm{bcd}$ & 5.05de & $4.46 d$ \\
\hline & 180 & 3,603abc & 4,057ab & 3.20 & 3.31 & 220.7 & 239.4 & $7.67 \mathrm{bc}$ & $6.67 \mathrm{~cd}$ & $5.34 \mathrm{~cd}$ & $5.38 \mathrm{bc}$ \\
\hline \multirow[t]{4}{*}{$\mathrm{HD}$} & 0 & $3,239 c$ & $1,913 d$ & 2.31 & 2.50 & 66.3 & 81.2 & $3.53 e$ & $3.00 \mathrm{e}$ & $5.86 c$ & $4.81 \mathrm{~cd}$ \\
\hline & 60 & $3,814 a b c$ & 4,232ab & 2.70 & 2.80 & 211.3 & 236.3 & $7.77 \mathrm{bc}$ & 8.00ab & $5.93 \mathrm{bc}$ & $5.39 \mathrm{bc}$ \\
\hline & 120 & 3,932ab & 4,155ab & 3.17 & 2.87 & 244.7 & 230.6 & 8.07ab & 7.67abc & 6.58ab & $5.65 b$ \\
\hline & 180 & 4,191a & 4,532a & 3.17 & 2.87 & 198.0 & 249.0 & $7.60 \mathrm{bc}$ & $7.00 \mathrm{bcd}$ & $7.08 a$ & $6.52 a$ \\
\hline Y & & \multicolumn{2}{|c|}{ ns } & \multicolumn{2}{|c|}{ ns } & \multicolumn{2}{|c|}{ ns } & \multicolumn{2}{|r|}{ ns } & \multicolumn{2}{|c|}{ ns } \\
\hline$D$ & & \multicolumn{2}{|c|}{$\star *$} & \multicolumn{2}{|c|}{ ns } & \multicolumn{2}{|c|}{ ns } & \multicolumn{2}{|r|}{ * } & \multicolumn{2}{|l|}{$\star \star$} \\
\hline N & & \multicolumn{2}{|c|}{ 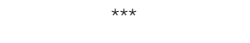 } & \multicolumn{2}{|c|}{ 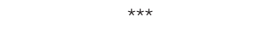 } & \multicolumn{2}{|c|}{$\star *$} & \multicolumn{2}{|r|}{ 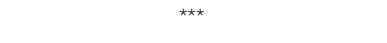 } & \multicolumn{2}{|l|}{ ** } \\
\hline$Y \times D$ & & \multicolumn{2}{|c|}{ ns } & & ns & & & & ns & ns & \\
\hline $\mathrm{Y} \times \mathrm{N}$ & & & & & ns & & & & ns & ns & \\
\hline $\mathrm{D} \times \mathrm{N}$ & & & & & ns & & & & * & * & \\
\hline$D \times N \times Y$ & & & & & ns & & & & * & ns & \\
\hline
\end{tabular}

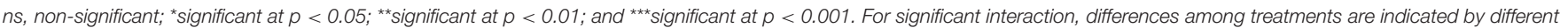
lowercase letters; for non-significant interaction, differences within treatment are indicated by uppercase letters.

\section{Lodging Resistance, LRI, and Lodging-Related Traits}

Lodging resistance and LRI were affected significantly by plant density and nitrogen. Lodging resistance was increased by increasing the density from 10 to 30 , but it decreased by further increase of density to 60 plants $\mathrm{m}^{-2}$ (Table 4). $\mathrm{N}$ application increased significantly the lodging resistance, peaking at $120 \mathrm{~kg}$ $\mathrm{ha}^{-1} . \mathrm{D} \times \mathrm{N}$ affected the lodging resistance, with the maximum resistance observed at $\mathrm{MD}$ at $120 \mathrm{~kg} \mathrm{~N} \mathrm{ha}^{-1}$ and the minimum at LD without N. The LRI at LD and MD decreased and at HD increased with increasing the $\mathrm{N}$. The maximum value of LRI recorded at $\mathrm{HD}$ was at $180 \mathrm{~kg} \mathrm{~N} \mathrm{ha}^{-1}$ and the minimum at MD at $120 \mathrm{~kg} \mathrm{~N} \mathrm{ha}^{-1}$ in both growing seasons.

The effects of density and $\mathrm{N}$ rates on some lodging-related morphological traits were studied (Figure 1). Plant height increased by increasing $\mathrm{N}$ levels, whereas it decreased at high plant density; the maximum height was observed at LD with $180 \mathrm{~kg} \mathrm{~N}$ and the minimum at HD without $\mathrm{N}$ in both growing seasons (Figure 1A). The shoot dry weight was increased with increasing nitrogen rates, reaching a peak at $180 \mathrm{~kg} \mathrm{ha}^{-1}$ for all three plant densities. Shoot dry weight was more at LD and MD which was reduced at HD (Figure 1B). The root neck diameter and root dry weights were increased by $\mathrm{N}$ rate in both growing seasons, reaching a peak at $180 \mathrm{~kg} \mathrm{~N} \mathrm{ha}^{-1}$ for all three plant densities.

\section{Net Photosynthetic Rate, Light Interception, and Nitrogen Use Efficiency}

Density affected significantly the net photosynthetic rate and LIR; both reached a peak at 30 plants $\mathrm{m}^{-2}$ and then declined as density increased to 60 plants $\mathrm{m}^{-2}$ (Table 4). The net photosynthetic rate and LIR at LD and MD showed a significant increase as $\mathrm{N}$ rate increased from 0 to $180 \mathrm{~kg} \mathrm{ha}^{-1}$. At $\mathrm{HD}$, LIR was increased by increasing $\mathrm{N}$ rate from 0 to $120 \mathrm{~kg} \mathrm{ha}^{-1}$, further increase of $\mathrm{N}$ rate to $180 \mathrm{~kg} \mathrm{ha}^{-1}$, decreased the LIR. The $\mathrm{D} \times$ $\mathrm{N}$ interaction significantly affected the net photosynthesis and 


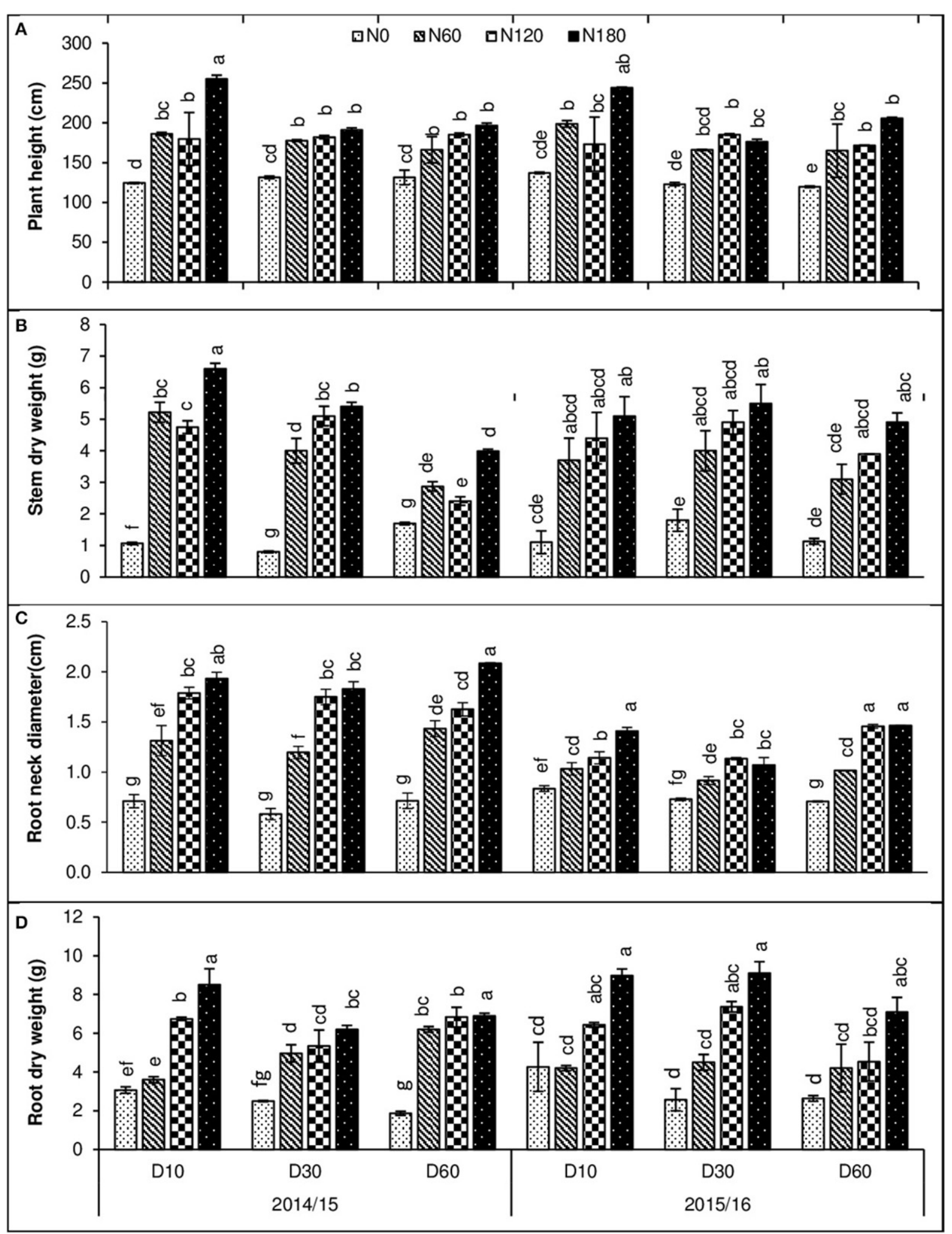

FIGURE 1 | Effect of plant densities $\left(\mathbf{1 0}, \mathbf{3 0}\right.$, and 60 plants $\left.\mathrm{m}^{-\mathbf{2}}\right)$ and $\mathbf{N}$ rates $\left(0,60, \mathbf{1 2 0}\right.$, and $180 \mathrm{~kg} \mathrm{ha}^{-1}$ ) on rapeseed, (A) plant height, (B) shoot dry weight, (C) root neck diameter, and (D) root dry weight in two consecutive growing seasons (2014/15 and 2015/16). Error bars indicate standard errors. Different letters indicate significant differences at $p<0.05$. 
TABLE 4 | Effect of plant densities and $\mathrm{N}$ rates on lodging resistance, lodging resistance index (LRI), photosynthetic rate ( $\boldsymbol{P}_{\mathrm{n}}$ ), light interception ratio (LIR), and apparent recovery nitrogen use efficiency in the growing season of 2014/15 (I) and 2015/16 (II).

\begin{tabular}{|c|c|c|c|c|c|c|c|c|c|c|c|}
\hline & & \multicolumn{2}{|c|}{ LR (kg cm) } & \multicolumn{2}{|c|}{ LRI (\%) } & \multicolumn{2}{|c|}{$P_{n}\left(\mu \mathrm{mol} \mathrm{m}{ }^{-2} \sec ^{-1}\right)$} & \multicolumn{2}{|c|}{ LIR (\%) } & \multicolumn{2}{|c|}{$\mathrm{N}$ use efficiency (\%) } \\
\hline & & I & II & $\mathbf{I}$ & II & I & II & $\mathbf{I}$ & II & I & II \\
\hline \multicolumn{12}{|c|}{ TREATMENTS } \\
\hline \multirow[t]{3}{*}{ Density } & LD & 4.12 & 4.03 & 2.01 & 1.56 & 7.31 & 7.83 & 64.48 & 62.75 & 15.83B & $15.03 \mathrm{C}$ \\
\hline & $\mathrm{MD}$ & 7.30 & 5.60 & 1.99 & 1.23 & 9.40 & 6.47 & 72.05 & 70.13 & $21.83 \mathrm{~A}$ & $22.53 \mathrm{~A}$ \\
\hline & HD & 4.65 & 3.35 & 4.16 & 1.79 & 8.26 & 6.47 & 72.45 & 70.80 & $19.40 A$ & 17.97B \\
\hline \multirow[t]{4}{*}{ Nitrogen } & 0 & 5.31 & 3.91 & 3.29 & 1.85 & 4.30 & 4.00 & 66.07 & 66.03 & & \\
\hline & 60 & 5.46 & 4.85 & 3.10 & 1.54 & 8.45 & 7.14 & 68.30 & 66.63 & $21.57 \mathrm{~A}$ & $20.57 \mathrm{~A}$ \\
\hline & 120 & 5.45 & 4.41 & 1.95 & 1.48 & 10.11 & 7.75 & 71.87 & 66.87 & $20.13 \mathrm{~A}$ & 19.77A \\
\hline & 180 & 5.19 & 4.12 & 2.55 & 1.24 & 10.43 & 8.79 & 72.40 & 72.03 & 15.37B & $15.20 \mathrm{~B}$ \\
\hline \multicolumn{12}{|c|}{ INTERACTIONS } \\
\hline \multirow[t]{4}{*}{ LD } & 0 & $3.47 c$ & $1.77 \mathrm{c}$ & $3.55 a b c$ & $2.15 a$ & $4.27 e$ & $3.91 \mathrm{~g}$ & $60.6 e$ & $60.6 d$ & - & - \\
\hline & 60 & $3.77 \mathrm{c}$ & $4.40 b$ & $2.33 b c d e$ & $1.44 \mathrm{c}$ & $7.10 d$ & 6.91 cde & $62.4 \mathrm{e}$ & $62.6 \mathrm{bcd}$ & 19.1 & 16.4 \\
\hline & 120 & $3.73 \mathrm{c}$ & 4.97ab & $0.49 \mathrm{e}$ & $1.82 \mathrm{abc}$ & $8.71 \mathrm{bcd}$ & $9.37 \mathrm{ab}$ & $66.9 \mathrm{bcde}$ & $63.5 \mathrm{bcd}$ & 16.4 & 17.6 \\
\hline & 180 & $5.50 \mathrm{bc}$ & $4.97 a b$ & $1.66 \mathrm{cde}$ & 0.83de & $9.15 \mathrm{bcd}$ & $11.12 \mathrm{a}$ & 68.0bcde & $64.3 \mathrm{bcd}$ & 12.0 & 11.1 \\
\hline \multirow[t]{4}{*}{ MD } & 0 & $5.91 \mathrm{abc}$ & $5.53 a$ & 2.98abcde & $2.13 a b$ & $4.39 e$ & $3.92 \mathrm{~g}$ & $65.4 \mathrm{bcde}$ & $62.2 \mathrm{~cd}$ & - & - \\
\hline & 60 & $8.30 a$ & $5.63 a$ & 3.79abc & $1.51 \mathrm{bc}$ & $9.85 a b c$ & $8.83 \mathrm{bc}$ & $68.4 \mathrm{bcd}$ & $64.5 \mathrm{bcd}$ & 23.5 & 25.2 \\
\hline & 120 & $8.59 a$ & $5.73 a$ & $0.47 e$ & $0.56 \mathrm{e}$ & 11.09ab & $6.12 \mathrm{def}$ & 73.4abcd & $74.4 \mathrm{abc}$ & 24.1 & 22.5 \\
\hline & 180 & 6.38ab & $5.50 a$ & 0.73de & $0.72 \mathrm{de}$ & $12.28 \mathrm{a}$ & 7.00cde & $81.0 a$ & $79.4 a$ & 17.9 & 19.9 \\
\hline \multirow[t]{4}{*}{ HD } & 0 & 6.56ab & $4.43 b$ & 3.34abcd & $1.26 \mathrm{~cd}$ & $4.23 e$ & $4.17 \mathrm{fg}$ & $72.2 \mathrm{abc}$ & 75.3ab & - & - \\
\hline & 60 & $4.32 \mathrm{bc}$ & $4.53 b$ & 3.18abcd & 1.66abc & $8.41 \mathrm{~cd}$ & 5.69efg & 74.1abc & 72.8abcd & 22.1 & 20.1 \\
\hline & 120 & $4.03 b c$ & $2.53 c$ & $4.88 \mathrm{ab}$ & $2.07 \mathrm{ab}$ & $10.52 \mathrm{abc}$ & $7.77 \mathrm{bcd}$ & 75.3ab & $62.7 \mathrm{bcd}$ & 19.9 & 19.2 \\
\hline & 180 & $3.70 \mathrm{c}$ & $1.90 \mathrm{c}$ & $5.25 a$ & $2.18 \mathrm{a}$ & 9.86abc & $8.26 \mathrm{bc}$ & $68.2 \mathrm{bcd}$ & 72.4abcd & 16.2 & 14.6 \\
\hline Y & & \multicolumn{2}{|c|}{ ns } & \multicolumn{2}{|c|}{ ns } & \multicolumn{2}{|c|}{$\star$} & \multicolumn{2}{|c|}{$\mathrm{ns}$} & \multicolumn{2}{|c|}{ ns } \\
\hline D & & \multicolumn{2}{|c|}{$\star \star *$} & \multicolumn{2}{|c|}{$\star \star *$} & \multicolumn{2}{|c|}{$\star$} & \multicolumn{2}{|c|}{ * } & \multicolumn{2}{|c|}{$\star \star$} \\
\hline$N$ & & \multicolumn{2}{|c|}{ 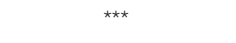 } & \multicolumn{2}{|c|}{ * } & \multicolumn{2}{|c|}{$\star \star$} & \multicolumn{2}{|c|}{$\star \star$} & \multicolumn{2}{|c|}{$\star \star$} \\
\hline$Y \times D$ & & \multicolumn{2}{|c|}{ ns } & & & & & & & & \\
\hline$Y \times N$ & & & & & & & & & & & \\
\hline $\mathrm{D} \times \mathrm{N}$ & & & & & & & & & & & \\
\hline $\mathrm{D} \times \mathrm{N} \times \mathrm{Y}$ & & & & & & & & & & & \\
\hline
\end{tabular}

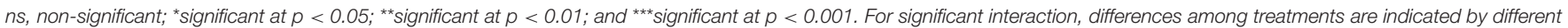
lowercase letters; for non-significant interaction, differences within treatment are indicated by uppercase letters.

LIR; the minimum values of both were observed at LD without $\mathrm{N}$. Within the same density rate, NUE was declined by increasing the $\mathrm{N}$ rate, in contrast to which by increasing density rate from 10 to 30 plants $\mathrm{m}^{-2}$ NUE was increased, and at 60 plants $\mathrm{m}^{-2}$ was also higher than 10 plants $\mathrm{m}^{-2}$.

\section{Correlation of Lodging Resistance with Yield and Other Traits}

Lodging resistance was significantly and positively correlated with seed yield, shoot and root dry weight, root neck diameter, and pods per plant but negatively related with plant height and lodging resistance index. Seed yield was positively correlated with plant height, root neck diameter, and root dry weight (Table 5).

\section{DISCUSSION}

Plant density is an important factor for establishing a uniform crop stand to ensure high yield. Moreover, $\mathrm{N}$ is probably the most important nutrient in rapeseed production because its deficiency results in yield reduction (Jackson, 2000; Begdelo et al., 2011). In the present study, seed yield increased with increasing plant density and $\mathrm{N}$ rate, reaching a peak at high density (HD) and $180 \mathrm{~kg} \mathrm{~N} \mathrm{ha}^{-1}$. Ahmadi and Bahrani (2009) reported the highest yield for rapeseed at $\mathrm{N}$ concentration of $225 \mathrm{~kg} \mathrm{ha}^{-1}$. This linear relationship between seed yield and $\mathrm{N}$ rate could be attributed to higher number of pods per plant, seeds per pods, and seedcarrying pods (Ghanbari-Malidarreh, 2010; Imran et al., 2014).

In present study, $\mathrm{N}$ use efficiency was improved with increasing the density rate from 10 plants $\mathrm{m}^{-2}$ to 30 and 60 plants $\mathrm{m}^{-2}$. Li et al. (2014) compared two plant density levels and reported that high density $\left(45\right.$ plants $\mathrm{m}^{-2}$ ) in rapeseed improved $\mathrm{N}$ use efficiency compared to low density of 15 plants $\mathrm{m}^{-2}$. The present study showed that $\mathrm{N}$ use efficiency was less at $180 \mathrm{~kg}$ $\mathrm{N} \mathrm{ha}^{-1}$ as compared to lower applied $\mathrm{N}$ rates. It indicated that rapeseed plants were unable to uptake $\mathrm{N}$ at high $\mathrm{N}$ rate because the supply of $\mathrm{N}$ in excess of plant requirement and possibility exists for the loss of $\mathrm{N}$ by leaching and denitrification. Plant $\mathrm{N}$ concentration and $\mathrm{N}$ use efficiency mostly decline at the maturity 


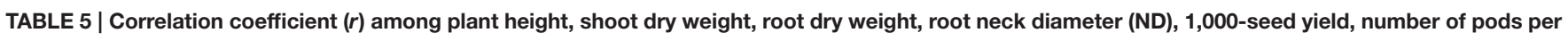
plant, lodging resistance (LR), and lodging resistance index (LRI) in rapeseed.

\begin{tabular}{|c|c|c|c|c|c|c|c|c|}
\hline Traits & Plant height & Shoot DW & Root DW & Root ND & Seed yield & Pods plant ${ }^{-1}$ & LR & LRI \\
\hline Plant height & - & - & - & - & - & - & - & - \\
\hline Shoot DW & $0.31^{\star \star}$ & - & - & - & - & - & - & - \\
\hline Root DW & $0.29^{\star}$ & $0.80^{\star \star \star}$ & - & - & - & - & - & - \\
\hline Root ND & $0.41^{\star \star \star}$ & $0.44^{\star \star \star}$ & $0.37^{\star \star}$ & - & - & - & - & - \\
\hline Seed yield & $0.43^{\star \star \star}$ & $0.15 n s$ & $0.65^{\star \star \star}$ & $0.46^{\star \star \star}$ & - & - & - & - \\
\hline Pods plant ${ }^{-1}$ & $0.59^{\star \star \star}$ & $0.63^{\star \star \star}$ & $0.61^{\star \star \star}$ & $0.57^{\star \star \star}$ & $0.38^{\star \star \star}$ & - & - & - \\
\hline LR & $0.03 n s$ & $0.29^{\star}$ & $0.30^{\star \star}$ & $0.44^{\star \star \star}$ & $0.49^{\star \star \star}$ & $0.39^{\star \star \star}$ & - & - \\
\hline LRI & $0.31^{*}$ & $0.03 n s$ & $0.02 \mathrm{~ns}$ & $0.04 \mathrm{~ns}$ & $-0.20 n s$ & $0.15 \mathrm{~ns}$ & $-0.29^{*}$ & - \\
\hline
\end{tabular}

ns, non-significant; * significant at $p<0.05$; ${ }^{* *}$ significant at $p<0.01$; and ${ }^{\star \star *}$ significant at $p<0.001$.

stage due to the greater dry matter accumulation rate than $\mathrm{N}$ accumulation rate (Chamorro et al., 2002). Significant proportion of leaf $\mathrm{N}$ was not mobilized before abscission of leaves during flowering and pod filling resulting in low $\mathrm{N}$ recovery by plant at maturity (Malagoli et al., 2005).

In the present study, the number of branches was greater at low plant density (LD) and the highest applied $\mathrm{N}$ rate $\left(\mathrm{N}_{180}\right)$. Tunçtürk and Çiftçi (2007) reported a positive correlation between seed yield and the number of branches. However, in the present study, the seed yield was greater at higher plant density despite the lesser number of branches and pods per plant, which might be correlated with increased lodging resistance due to reduced plant height and greater number of plants with uniform canopy at higher densities. Li et al. (2014) reported that increasing planting density from 15 to 45 plants $\mathrm{m}^{-2}$ significantly decreases plant height, branch number, and effective pod number per plant and thereby makes the canopy uniform. Less competition for assimilates at low plant density stimulates the growth of the apical and lateral meristems, resulting in higher number of branches and uneven, delayed maturation (Inamullah et al., 2013). Our results showed that the number of branches increased with $\mathrm{N}$ application; however, the number of branches decreased with increasing plant density at $\mathrm{N}_{120}$ and $\mathrm{N}_{180}$, probably because at high $\mathrm{N}$ rates, plant growth is more vigorous and the increase in plant density negatively affects the number of branches (Ozer, 2003). Low planting density promotes plant growth, leading to taller plants with increased number of branches and pods per plants. Such plants require more nitrogen as compared to plants at higher densities (Šidlauskas and Tarakanovas, 2004). $\mathrm{N}$ application also increased the number of pods per plant in both growing seasons, which could be attributed to a higher number of pod-bearing branches (Ozer, 2003).

Lodging is a serious obstacle for rapeseed production particularly in rapeseed growing areas of Yangtze River basin, receiving high rainfall. Resistance to lodging depends on morphological, physiological, and biochemical traits and is related to stem strength, plant height, wall thickness, lignin content, and center of gravity (Kong et al., 2013; Chen et al., 2014; Ookawa et al., 2014). Lodging resistance (LR) and lodging resistance index (LRI) are closely associated with the actual lodging score at the field level (Islam et al., 2007). In the present study, at medium density (30 plants $\mathrm{m}^{-2}$ ), LR increased with $\mathrm{N}$ application, reaching a peak at $120 \mathrm{~kg} \mathrm{ha}^{-1}$, but decreased by further increase to $180 \mathrm{~kg} \mathrm{ha}^{-1}$, whereas at high density rate (60 plants $\mathrm{m}^{-2}$ ), LR was decreased with increasing $\mathrm{N}$ rate. Zhang et al. (2014) reported an increase in lodging due to $\mathrm{N}$ application, which was associated with enhanced plant growth and height. Similarly, LR increased with increasing the plant density up to 30 plants $\mathrm{m}^{-2}$, which was then followed by a decrease at the highest studied density $\left(60\right.$ plants $\left.\mathrm{m}^{-2}\right)$. Previous studies showed that the risk of lodging increases under conditions of relatively high plant density because of the longer basal internode, higher center of gravity, and decreased shoot diameter of plants (Mobasser et al., 2008, 2009; Xiao et al., 2015). In the present study, LR showed positive correlation with seed yield and dry biomass, whereas the correlation with plant height was non-significant. The maximum LR was recorded at $\mathrm{MD}$ using $120 \mathrm{~kg} \mathrm{~N}^{-1}$ and the minimum plant height was at HD without $\mathrm{N}$. Therefore, minimum plant height does not warrant high lodging resistance and is not necessarily the most important factor determining lodging resistance (Ookawa and Ishihara, 1992). Plant height could be increased without affecting the lodging if the breaking resistance and dry weight per unit length are also increased (Islam et al., 2007). In the present study, the shoot and root dry weight and the root neck diameter were increased with increasing plant density and nitrogen rate, reaching a peak at highest used $\mathrm{N}(180 \mathrm{~kg}$ $\mathrm{ha}^{-1}$ ), which might be another possible reason for increased lodging resistance in plants. Root traits are also valuable for determining lodging, since resistant genotypes usually have a well-developed root system that increases the anchorage strength of the plant.

LRI is an important parameter for estimating lodging. This index is affected by a number of plant traits such as plant height, shoot weight, stem thickness, and breaking strength (Yang et al., 2000; Mobasser et al., 2009; Peng et al., 2014). Our results showed that the minimum LRI was found at medium density (30 plants $\mathrm{m}^{-2}$ ) along with $120 \mathrm{~kg} \mathrm{~N} \mathrm{ha}^{-1}$. Increasing density (60 plants $\mathrm{m}^{-2}$ ) and $\mathrm{N}\left(180 \mathrm{~kg} \mathrm{ha}^{-1}\right)$ then increased the LRI and thus weaker lodging resistance, which subsequently causes lodging and yield losses. A negative relationship between LR and plant height indicated that increase in plant height reduces the lodging resistance of rapeseed. Increase in breaking resistance of lower internodes and dry biomass per unit length are the main morphological traits responsible for reduction in the lodging index and thus the induction of lodging resistance (Islam et al., 2007). 
In the present study, light interception ratio (LIR) and photosynthetic rate was at peak at highest $\mathrm{N}\left(180 \mathrm{~kg} \mathrm{ha}^{-1}\right)$ and medium plant density (MD), whereas decreased at lowest (10 plants $\mathrm{m}^{-2}$ ) and highest density (60 plants $\mathrm{m}^{-2}$ ) rates. It is known that LIR is related to biomass production-relatively high plant densities hasten canopy interception and increase yield (Portes and Melo, 2014), whereas solar radiation is not fully intercepted at relatively low plant densities (Atwell et al., 1999). Concurrently, relatively high plant densities do not allow light to reach lower shoot sections, triggering shoot elongation. However, if the quantity and quality of light are not disturbed, the shoot elongation rate is not affected by plant density (Holmes and Smith, 1977). Plant density affects photosynthesis by influencing the radiation interception and the structure of the canopy (Ma et al., 2014). Since lodging may reduce the photosynthetic capacity of the canopy, another target is needed to improve lodging resistance. However, relatively high plant densities are negatively correlated with photosynthetically active radiation (Tetio-Kagho and Gardner, 1988). These results indicated that rapeseed yield might be improved by selecting the density and nitrogen rates at which plants have optimum height, shorter basal internodes, and uniform canopy with high light interceptiontraits that are associated with higher lodging resistance (Zhang et al., 2014).

\section{CONCLUSION}

Increasing plant density and nitrogen rate to the maximum studied rates significantly increased the seed yield. Lodging resistance was increased by increasing plant density from 10 to

\section{REFERENCES}

Ahmadi, M., and Bahrani, M. J. (2009). Yield and yield components of rapeseed as influenced by water stress at different growth stages and nitrogen levels. Am. Eurasian J. Agric. Environ. Sci. 5, 755-761. Available online at: http://www.idosi. org/aejaes/jaes5(6)/6.pdf

Al-Barzinjy, M., Stølen, O., Christiansen, J. L., and Jensen, J. E. (1999). Relationship between plant density and yield for two spring cultivars of oilseed rape (Brassica napus L.). Acta Agric. Scand. B Soil Plant Sci. 49, 129-133. doi: 10.1080/09064719908565559

Atwell, B. J., Kriedemann, P. E., and Turnbull, C. G. (1999). Plants in Action: Adaptation in Nature, Performance in Cultivation. South Yarra, VIC: Macmillan Education Australia.

Bagheri, H., Zafarian, R., and Faradonbeh, O. P. (2011). The effect of different planting densities on agronomy traits of canola varieties in Chaloos, Iran. Res. Opin. Anim. Vet. Sci. 1, S52-S55. Available online at: http://www.roavs.com/ pdf-files/special_issue/S52-S55.pdf

Begdelo, M., Shirani Rad, A. H., Noormohammadi, G., and Tajalli, A. A. (2011). Nitrogen rates effect on some agronomic traits of turnip rape under different irrigation regimes. Asian J. Agric. Res. 5, 243-249. doi: 10.3923/ajar.2011.243.249

Berry, P. M., Spink, J., Foulkes, M. J., and White, P. J. (2010). The physiological basis of genotypic differences in nitrogen use efficiency in oilseed rape (Brassica napus L.). Field Crops Res. 119, 365-373. doi: 10.1016/j.fcr.2010. 08.004

Black, C. A. (1965). Methods of Soil Analysis. Agronomy No. 9. Part 2. Madison, WI: American Society of Agronomy.

Bouchet, A. S., Laperche, A., Bissuel-Belaygue, C., Snowdon, R., Nesi, N., and Stahl, A. (2016). Nitrogen use efficiency in rapeseed. A review. Agron. Sustain. Dev. 36, 1-20. doi: 10.1007/s13593-016-0371-0
30 plants $\mathrm{m}^{-2}$ and $\mathrm{N}$ from 0 to $120 \mathrm{~kg} \mathrm{ha}^{-1}$ and decreased by further increase in density and $\mathrm{N}$ rate. The net photosynthetic rate and light interception showed same trend-reached a peak at 30 plants $\mathrm{m}^{-2}$ at $180 \mathrm{~kg} \mathrm{~N} \mathrm{ha}^{-1}$. $\mathrm{N}$ use efficiency was increased at higher plant density and decrease by increasing $\mathrm{N}$ rates. It might be concluded from these results that the density rate of 30 plants $\mathrm{m}^{-2}$ and $180 \mathrm{~kg} \mathrm{~N} \mathrm{ha}^{-1}$ is appropriate to attain high yield of rapeseed, $\mathrm{N}$ use efficiency and lodging resistance in winter rapeseed.

\section{AUTHOR CONTRIBUTIONS}

GZ designed and supervised the research project. SK performed the experiments and collected the data. SU helped in data collection. SK and SA analyzed the data and wrote the manuscript. JK and SF revised and edited the manuscript and also provided advice on the experiment. GZ read and approved the final manuscript.

\section{ACKNOWLEDGMENTS}

The authors wish to thank the mediums and sitters who volunteered their time for this study. This research was supported by the National Key Technology Research and Development Program (2014BAD11B03), the Industry Technology Research Institute (CARS-13), the Special Funds for Public Welfare Industry (Agriculture) Study of China (2012203096) and the Fundamental Research Funds for the Central Universities (2013PY001; 2015BQ001).

Bremner, J. M. (1965). "Total nitrogen," in Methods of Soil Analysis: Chemical and Microbiological Properties. Part II, ed C. A. Black (Madison, WI: American Society of Agronomy), 1238-1255.

Chamorro, A. M., Tamagno, L. N., Bezus, R., and Sarandón, S. J. (2002). Nitrogen accumulation, partition, and nitrogen-use efficiency in canola under different nitrogen availabilities. Commun. Soil Sci. Plant Anal. 33, 493-504. doi: 10.1081/CSS-120002759

Chen, W. Y., Liu, Z. M., Deng, G. B., Pan, Z. F., Liang, J. J., Zeng, X. Q., et al. (2014). Genetic relationship between lodging and lodging components in barley (Hordeum vulgare) based on unconditional and conditional quantitative trait locus analyses. Genet. Mol. Res. 13, 1909-1925. doi: 10.4238/2014.March.17.19

Food and Agriculture Organization of the United Nations, (FAOSTAT) (2017). Available online at: http://www.fao.org.

Ghanbari-Malidarreh, A. (2010). Effects of nitrogen rates and splitting on oil content and seed yield of canola (Brassica napus L.). Am. Eurasian J. Agric. Environ. Sci. 8, 161-166. Available online at: https://www.idosi.org/aejaes/ jaes8(2)/7.pdf

Holmes, M. G., and Smith, H. (1977). The function of phytochrome in the natural environment-II. The influence of vegetation canopies on the spectral energy distribution of natural daylight. Photochem. Photobiol. 25, 539-545. doi: 10.1111/j.1751-1097.1977.tb09125.x

Hu, Q., Hua, W., Yin, Y., Zhang, X., Liu, L., Shi, J., et al. (2016). Rapeseed research and production in China. Crop. J. 5, 127-135.

Imran, Khan, A. A., Irfanullah, and Ahmad, F. (2014). Production potential of rapeseed (Brassica napus L.) as influenced by different nitrogen levels and decapitation stress under the rainfed agro-climatic condition of Swat-Pakistan. J. Glob. Innov. Agric. Soc. Sci. 2, 112-115.

Inamullah, Khan, B., Din, M., Siddiq, M., Khan, A. A., Munir, A., et al., (2013). Effect of various seed rates and nitrogen levels on the productivity of late sown Brassica. Sarhad J. Agric. 29, 503-509. Available online at: https:// 
www.aup.edu.pk/sj_pdf/3\%20304-2013\%20EFFECT\%20OF\%20VARIOUS \%20SEED\%20RATES\%20AND\%20NITROGEN\%20LEVELS\%20ON\%20THE \%20PRODUCTIVITY\%20OF\%20LATE\%20SOWN\%20BRASSICA.pdf

Islam, M. S., Peng, S., Visperas, R. M., Ereful, N., Bhuiya, M. S. U., and Julfiquar, A. W. (2007). Lodging-related morphological traits of hybrid rice in a tropical irrigated ecosystem. Field Crops Res. 101, 240-248. doi: 10.1016/j.fcr.2006.12.002

Jackson, G. D. (2000). Effects of nitrogen and sulfur on canola yield and nutrient uptake. Agron. J. 92, 644-649. doi: 10.2134/agronj2000.924644x

Kazemeini, S. A., Edalat, M., Shekoofa, A., and Hamidi, R. (2010). Effects of nitrogen and plant density on rapeseed (Brassica napus L.) yield and yield components in Southern Iran. J. Appl. Sci. 10, 1461-1465. doi: $10.3923 /$ jas.2010.1461.1465

Keeney, D. R. (1982). "Nitrogen management for maximum efficiency and minimum pollution," in Nitrogen in Agricultural Soils, Agronomy Monograph 22, ed F. J. Stevenson (Madison, WI: ASA, CSSA, and SSSA), 605-649.

Knudsen, D. G., Peterson, A., and Pratt, P. F. (1982). "Lithium, sodium and potassium," in Methods Soil Analysis. Part 2. Agronomy Monograph 9, ed A. L. Page (Madison, WI: ASA and SSSA), 247-262.

Kong, E., Liu, D., Guo, X., Yang, W., Sun, J., Li, X., et al. (2013). Anatomical and chemical characteristics associated with lodging resistance in wheat. Crop J. 1 , 43-49. doi: 10.1016/j.cj.2013.07.012

Li, S. Y., Yu, C. B., Zhu, S., Xie, L. H., Hu, X. J., Liao, X., et al. (2014). High planting density benefits to mechanized harvest and nitrogen application rates of oilseed rape (Brassica napus L.). Soil Sci. Plant Nutr. 60, 384-392. doi: 10.1080/00380768.2014.895417

Li, X., Li, Q., Yang, T., Nie, Z., Chen, G., and Hu, L. (2016). Responses of plant development, biomass and seed production of direct sown oilseed rape (Brassica napus) to nitrogen application at different stages in Yangtze River Basin. Field Crops Res. 194, 12-20. doi: 10.1016/j.fcr.2016.04.024

Liu, T., Song, F., Liu, S., and Zhu, X. (2012). Light interception and radiation use efficiency response to narrow-wide row planting patterns in maize. Aust. J. Crop Sci. 6, 506-513. http://www.cropj.com/liu_5_3_2012_506_513.pdf

Ma, N., Yuan, J., Li, M., Li, J., Zhang, L., Liu, L., et al. (2014). Ideotype population exploration: growth, photosynthesis, and yield components at different planting densities in winter oilseed rape (Brassica napus L.). PLoS ONE 9:e114232. doi: 10.1371/journal.pone.0114232

Malagoli, P., Laine, P., Rossato, L., and Ourry, A. (2005). Dynamics of nitrogen uptake and mobilization in field-grown winter oilseed rape (Brassica napus) from stem extension to harvest I. Global $\mathrm{N}$ flows between vegetative and reproductive tissues in relation to leaf fall and their residual N. Ann. Bot. 95, 853-861. doi: 10.1093/aob/mci091

Mobasser, H. R., Ghadikolaee, M. S., Nasiri, M., Daneshian, J., Tari, D. B., and Pourkalhor, H. (2008). Effect of nitrogen rates and plant density on the agronomic traits of canola (Brassica napus L.) in paddy field. Asian J. Plant Sci. 7, 233-236. doi: 10.3923/ajps.2008.233.236

Mobasser, H. R., Yadi, R., Azizi, M., Ghanbari, A. M., and Samdaliri, M. (2009). Effect of density on morphological characteristics related-lodging on yield and yield components in varieties rice (Oryza sativa L.) in Iran. Am. Eurasian J. Agric. Environ. Sci. 5, 745-754. Available online at: https://www.idosi.org/ aejaes/jaes5(6)/5.pdf

Ookawa, T., and Ishihara, K. (1992). Varietal difference of physical characteristics of the culm related to lodging resistance in paddy rice. Jpn. J. Crop Sci. 61, 419-425. doi: 10.1626/jcs.61.419

Ookawa, T., Inoue, K., Matsuoka, M., Ebitani, T., Takarada, T., Yamamoto, T., et al. (2014). Increased lodging resistance in long-culm, low-lignin gh2 rice for improved feed and bioenergy production. Sci. Rep. 4, 65-67. doi: $10.1038 /$ srep 06567

Ozer, H. (2003). The effect of plant population densities on growth, yield and yield components of two spring rapeseed cultivars. Plant Soil Environ. 49, 422-426. Available online at: http://agriculturejournals.cz/publicFiles/52889. pdf

Peng, D., Chen, X., Yin, Y., Lu, K., Yang, W., Tang, Y., et al. (2014). Lodging resistance of winter wheat (Triticum aestivum L.): lignin accumulation and its related enzymes activities due to application of paclobutrazol or gibberellin acid. Field Crops Res. 157, 1-7. doi: 10.1016/j.fcr.2013.11.015

Portes, T. A., and Melo, H. C. (2014). Light interception, leaf area and biomass production as a function of the density of maize plants analyzed using mathematical models. Acta Sci. Agron. 36, 457-463. doi: 10.4025/actasciagron.v36i4.17892

Purcell, L. C., Ball, R. A., Reaper, J. D., and Vories, E. D. (2002). Radiation use efficiency and biomass production in soybean at different plant population densities. Crop Sci. 42, 172-177. doi: 10.2135/cropsci2002.0172

Raey, Y., and Ghassemi-Golezani, K. (2009). Yield-density relationship for potato (Solanum tuberosum) and common bean (Phaseolus vulgaris) in intercropping. N. Z. J. Crop Hortic. Sci. 37, 141-147. doi: 10.1080/01140670909510259

Sidlauskas, G., and Bernotas, S. (2003). Some factors affecting seed yield of spring oilseed rape (Brassica napus L.). Agron. Res. 1, 229-243. Available online at: http://agronomy.emu.ee/vol012/Sidlauskas.pdf

Šidlauskas, G., and Tarakanovas, P. (2004). Factors affecting nitrogen concentration in spring oilseed rape (Brassica napus L). Plant Soil Environ. 50, 227-234. Available online at: http://www.agriculturejournals.cz/publicFiles/ 52752.pdf

Sieling, K., and Kage, H. (2010). Efficient N management using winter oilseed rape. A review. Agron. Sustain. Dev. 30, 271-279. doi: 10.1051/agro/2009036

Sylvester-Bradley, R., and Kindred, D. R. (2009). Analysing nitrogen responses of cereals to prioritize routes to the improvement of nitrogen use efficiency. J. Exp. Bot. 60, 1939-1951. doi: 10.1093/jxb/erp116

Tetio-Kagho, F., and Gardner, F. P. (1988). Response of maize to plant population density. I. Canopy development, light relationships, and vegetative growth. Agron. J. 80, 930-935. doi: 10.2134/agronj1988.00021962008000060018x

Tunçtürk, M. and Çiftçi, V. (2007). Relationships between yield and some yield components in rapeseed (Brassica napus ssp. oleifera L.) cultivars by using correlation and path analysis. Pak. J. Bot. 39, 81-84. Available online at: http:// www.pakbs.org/pjbot/PDFs/39(1)/PJB39(1)081.pdf

Walkley, A., and Black, I. A. (1934). An examination of the Degtjareff method for determining soil organic matter, and a proposed modification of the chromic acid filtration method. Soil Sci. 37, 29-38. doi: 10.1097/00010694-193401000-00003

Wang, C. Y., Dai, X. L., Shi, Y. H., Wang, Z. L., Chen, X. G., and He, M. R. (2012). Effects of nitrogen application rate and plant density on lodging resistance in winter wheat. Acta Agron. Sin. 38, 121-128. doi: 10.3724/SP.J.1006.2012. 00121

Wang, C., Hu, D., Liu, X., She, H., Ruan, R., Yang, H., et al. (2015). Effects of uniconazole on the lignin metabolism and lodging resistance of culm in common buckwheat (Fagopyrum esculentum M.). Field Crops Res. 180, 46-53. doi: 10.1016/j.fcr.2015.05.009

Wang, R., Cheng, T., and Hu, L. (2015). Effect of wide-narrow row arrangement and plant density on yield and radiation use efficiency of mechanized direct-seeded canola in central China. Field Crops Res. 172, 42-52. doi: 10.1016/j.fcr.2014.12.005

Xiao, Y., Liu, J., Li, H., Cao, X., Xia, X., and He, Z. (2015). Lodging resistance and yield potential of winter wheat: effect of planting density and genotype. Front. Agric. Sci. Eng. 2, 168-178. doi: 10.15302/J-FASE-2015061

Yang, H. J., Yang, R. C., Li, Y. Z., Jiang, Z. W., and Zheng, J. S. (2000). The relationship between culm traits and lodging resistance of rice cultivars. Fujian J. Agric. Sci. 15, 1-7. Available online at: https://www.cabdirect.org/cabdirect/ abstract/20001617824

Zhang, J., Li, G., Songa, Y., Liu, Z., Yang, C., Tang, S., et al. (2014). Lodging resistance characteristics of high-yielding rice populations. Field Crops Res. 161, 64-74. doi: 10.1016/j.fcr.2014.01.012

Zhang, W., Li, G., Yang, Y., Li, Q., Zhang, J., Liu, J., et al. (2013). Effects of nitrogen application rate and ratio on lodging resistance of super rice with different genotypes. J. Integr. Agric. 13, 63-72. doi: 10.1016/S2095-3119(13)60388-3

Conflict of Interest Statement: The authors declare that the research was conducted in the absence of any commercial or financial relationships that could be construed as a potential conflict of interest.

Copyright $\odot 2017$ Khan, Anwar, Kuai, Ullah, Fahad and Zhou. This is an openaccess article distributed under the terms of the Creative Commons Attribution License (CC BY). The use, distribution or reproduction in other forums is permitted, provided the original author(s) or licensor are credited and that the original publication in this journal is cited, in accordance with accepted academic practice. No use, distribution or reproduction is permitted which does not comply with these terms. 